\title{
Manipulation of reproductive seasonality using melatonin implantation in Anglo-Nubian does treated with controlled internal drug release and equine chorionic gonadotropin during the nonbreeding season ${ }^{1}$
}

\author{
M. Y. El-Mokadem, ${ }^{*}$ A. N. M. Nour El-Din, $\dagger$ T. A. Ramadan, ${ }^{*}$ A. M. A. Rashad, $\dagger$ T. A. Taha, $\dagger^{2}$ and M. A. Samak $\dagger$ \\ *Animal Production Research Institute, Agricultural Research Center, 4 Nadi El-Said, 12311 Dokki, Giza, Egypt \\ †Animal Production Department, Faculty of Agriculture (El-Shatby), Alexandria University, Alexandria 22545, Egypt
}

\begin{abstract}
The objective of this study was to compare the efficiency of hormonal treatments on ovarian activity and reproductive performance in anestrous Anglo-Nubian does during the nonbreeding season (February to May). A total of 48 multiparous does were divided into 2 groups (24 lactating does and 24 dry does). In each group, animals were allocated randomly into 2 equal subgroups (12 does each). In the first subgroup, does received a single 18-mg melatonin implant for $42 \mathrm{~d}$ followed by a controlled internal drug release (CIDR) device for $19 \mathrm{~d}$ in conjunction with $500 \mathrm{IU}$ of equine chorionic gonadotropin (eCG) i.m. on the day of CIDR device removal. The second subgroup received CIDR combined with eCG in parallel with the first subgroup. Melatonin implantation induced a luteotrophic effect, expressed as an increasing number of corpora lutea, increased serum progesterone concentration, and reduced estradiol concentration. Regardless of treatment, dry does showed greater value of progesterone concentration. With the advancement of day of treatment, number of total follicles, small follicles, and medium follicles tended to increase to the greatest values at the day of CIDR device insertion. Furthermore, at day of mating, the numbers of large follicles reached the greatest value, which was associated with the lowest value of the number of corpora lutea. At day of mating, serum progesterone concentration achieved the lowest value, which increased until d 56 of pregnancy. The estradiol:progesterone ratio showed the opposite trend. The detrimental effect of reproductive seasonality, expressed as cessation of estrus behavior and fertile mating during the nonbreeding season, was successfully alleviated by the CIDR-eCG protocol. Furthermore, melatonin implantation in conjunction with the CIDR-
\end{abstract}

Received November 1, 2016.

Accepted February 22, 2017.

${ }^{1}$ The authors have no conflicts of interest to declare.

${ }^{2}$ Corresponding author: tahaataha@yahoo.com
eCG protocol enhanced conception rate and fecundity at d 28 of pregnancy and prolificacy at d 56 of pregnancy compared with does that were not implanted. Interestingly, does that failed to conceive did not come to heat again. In conclusion, the beneficial effect of melatonin implantation in conjunction with the CIDReCG protocol on the luteotrophic effect was reflected in the increasing number of corpora lutea, increasing progesterone concentration, and decreasing estradiol concentration. Furthermore, conception rate, prolificacy, and fecundity were improved compared with does that were not implanted during the nonbreeding season.

Key words: melatonin, controlled internal drug release-equine chorionic gonadotropin protocol, reproductive seasonality, goat

\section{INTRODUCTION}

Goats ovulate spontaneously and are commonly considered to be seasonally polyestrous animals under temperate climatic conditions (Fatet et al., 2011). The photoperiod is one of the major factors that influence the reproductive activity in small ruminants (Bedos et al., 2014). Melatonin is the neuroendocrine signal that transduces information about the environmental light received by the retina. Reproductive activity of goats in subtropical regions is depressed from March to June (Mellado et al., 2014). In these regions, exogenously administered melatonin from continuous slow-release implants usually is inserted around the time of the spring equinox in goats (Zarazaga et al., 2012 a,b; Celi et al., 2013) to advance the onset of the breeding season by mimicking the stimulatory effect of short days (Zarazaga et al., 2009). These implants increase the concentration of melatonin without suppressing the endogenous secretion of melatonin (Zarazaga et al., 2011a). In goats, melatonin can induce ovarian and estrus activity during the seasonal anestrus (Zarazaga et al., 2011b) and increase conception rate (Kumar and Purohit, 2009) because it improves the rate of cleaved oocyte and enhancement of blastocyst output (Berlinguer et 
al., 2009), which is reflected in increasing fecundity and fertility (Celi et al., 2013). In addition, melatonin suppresses prolactin concentration (Yue et al., 2010), which is inversely related to the pattern of reproductive activity in goats (Mori et al., 1985). Furthermore, the beneficial effects of melatonin implantation in sheep have been expressed as improvement in ovulation rate (Zúñiga et al., 2002), luteal function (Durotoye et al., 1997; Abecia et al., 2002), and embryo viability (Forcada et al., 2006) and increased oocyte maturation rate. In addition, melatonin implantation tended to improve cleavage rate in in vitro fertilization (Casao et al., 2010). Applications of exogenous hormones for increased reproductive performance in goats are usually focused on estrus synchronization, which is achieved by control of the luteal phase of the estrus cycle, either by providing exogenous progesterone $\left(\mathbf{P}_{4}\right)$ or by inducing premature luteolysis (Fonseca et al., 2005). Synchronization of ovulation protocols out of season is commonly based on controlled internal drug release (CIDR) plus equine chorionic gonadotropin (eCG; Abecia et al., 2011), which has been considered to be an effective protocol for inducing estrus and ovulation in goats during the nonbreeding season (Contreras-Villarreal et al., 2016). The objective of this study was to determine the effects of melatonin implants in conjunction with a CIDR-eCG protocol on the induction of synchronized fertile estrus and pregnancy in seasonally anestrous dry and lactating Anglo-Nubian does.

\section{MATERIALS AND METHODS}

All procedures and experimental protocols were conducted in accordance with the Guide for the Care and Use of Agricultural Animals in Research and Teaching (FASS, 2010). This study was carried out using AngloNubian does during the nonbreeding season (from February to May) at the Agricultural Experimental Station $\left(31^{\circ} 20^{\prime} \mathrm{N}, 30^{\circ} \mathrm{E}\right)$, Alexandria University, Alexandria, Egypt.

\section{Animals and Management}

A total of 48 multiparous Anglo-Nubian does (24 dry, $\mathrm{BW}=31.52 \pm 1.58 \mathrm{~kg} ; 24$ lactating, $\mathrm{BW}=30.31 \pm$ $1.43 \mathrm{~kg}$ ) at their third to fourth parities were used. Animals were kept outdoors with shelter during the day and were housed in a semiopen barn at night. Animals were offered roughage and concentrate supplement according to their BW requirements (NRC, 2007). They were given Egyptian clover (Trifolium alexandrinum) in winter and spring and chopped green maize in summer and autumn in addition to hay. Each animal also re- ceived $1 \mathrm{~kg} / \mathrm{d}$ of a concentrate mixture (prepared at the Agriculture Experimental Station) consisting of $18 \%$ soybean meal, $40 \%$ wheat bran, $40 \%$ ground maize, and $2 \%$ limestone plus salt. The chemical analysis of the concentrate mixture according to the Association of Official Analytical Chemists (AOAC, 1984) indicated that it contained $16.04 \% \mathrm{CP}, 3.31 \%$ ether extract, $6.94 \%$ crude fiber, $67.76 \%$ carbohydrate, and $5.95 \%$ ash and offered $68 \%$ TDN. Free access to water was provided to animals at all times. Animals were free of any disease and were clinically normal with a healthy appearance.

\section{Experimental Design}

Forty-eight Anglo-Nubian does were divided into 2 groups (24 lactating and 24 dry). In each group animals were divided into 2 subgroups of 12 does each. The first subgroup was implanted with $2 \times 4 \mathrm{~mm}$ absorbable melatonin implants (18 mg of melatonin/implant; Melovine, Ceva Santé Animale, La Ballastière, Libourne, France) at the base of the left ear using an implanter. These implants are designed to release melatonin for at least $60 \mathrm{~d}$, although their functionality can extend to more than 100 d (Forcada et al., 2002) without disturbing the endogenous secretion of melatonin as seen in ewes (Forcada et al., 1995). On d 42 after melatonin implantation, all implanted does were treated with Eazi-Breed CIDR (0.3 g of $\mathrm{P}_{4}$; Pfizer Animal Health, Auckland, New Zealand), which were removed after $19 \mathrm{~d}$. On the day of CIDR removal (d 61), animals were injected i.m. with 500 IU of eCG (Syncropart, Ceva Santé Animale). Estrus signs of the females were detected using teaser bucks daily, and does that exhibited estrus were mated with fertile bucks (through $48 \mathrm{~h}$ after CIDR removal; Abecia et al., 2011). In the second subgroup, the CIDR was inserted at the same time as in the first subgroup, and the group thereafter received a similar protocol. In the lactating group, the experimental protocol was carried out on d 40 after parturition. Uterine involution has been reported to be completed by d 27 , so does can exert their first postpartum estrus after 5 to 10 wk after parturition (Hafez and Hafez, 2000). In all animals, pregnancy diagnosis was carried out by ultrasonography at d 28 and 56 after mating (representing d 91 and 119 of the experiment). The experimental layout is shown in Figure 1.

\section{Ovarian Activity and Pregnancy Diagnosis}

A real-time B-mode ultrasound scanner equipped with 5 - and $7.5-\mathrm{MHz}$ linear-array endorectal probes (Pie Medical Equipment B.V., Maastricht, the Netherlands) was used to determine the ovarian response 


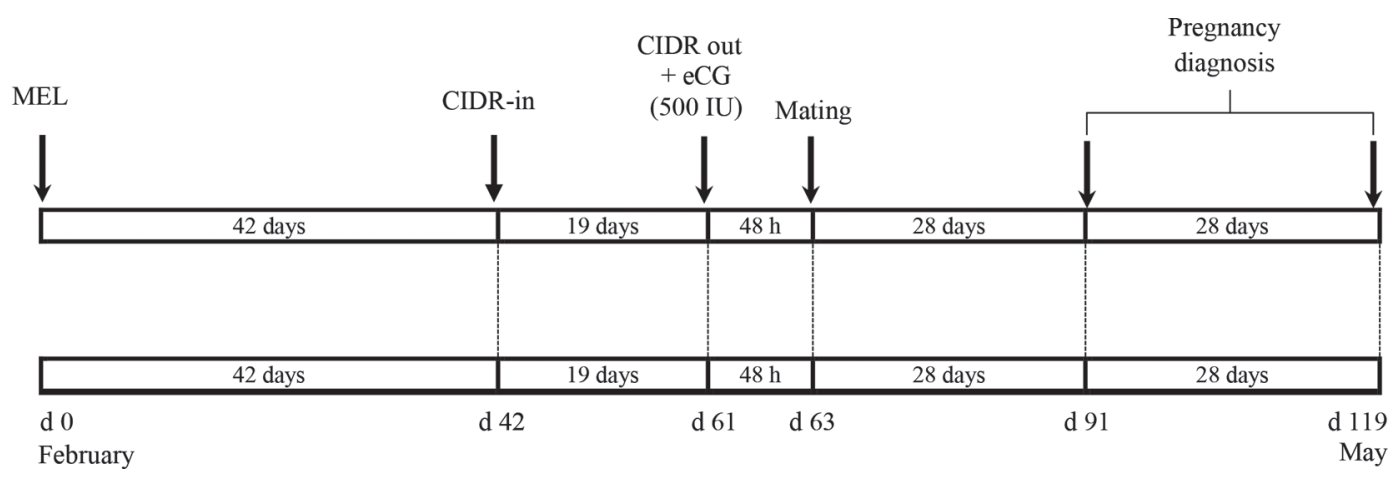

Figure 1. Experimental design to evaluate the effect of melatonin (MEL; $18 \mathrm{mg}$ ) implantation and a controlled internal drug release (CIDR; $0.3 \mathrm{~g}$ of progesterone)-equine chorionic gonadotropin (eCG; 500 IU of Syncropart, Ceva Santé Animale, La Ballastière, Libourne, France, i.m.) synchronization protocol in Anglo-Nubian does during the nonbreeding season.

to melatonin and CIDR treatment. The scanning procedure described by Gonzalez-Bulnes et al. (2010) was used. Briefly, animals were banned from feed for $12 \mathrm{~h}$ before examination, which was carried out in a standing position. The probe was fitted to a plastic rod $(1 \times 30$ $\mathrm{cm}$ ) as an adapter to enable the insertion of the probe into the rectum. The probe was lubricated by a hydrosoluble gel and sheathed with polyvinyl chloride pipe $(2 \times 35 \mathrm{~cm})$ to avoid damaging the rectal mucosa and was gently inserted about $20 \mathrm{~cm}$ through the rectum after feces removal until the anechoic content of the bladder was visible on the screen. Then the probe was rotated $90^{\circ}$ clockwise and $180^{\circ}$ counterclockwise across the reproductive tract until the uterine horns and both ovaries were scanned. Ovarian activity, including total number of follicles $2 \mathrm{~mm}$ or greater per doe and follicle population (i.e., small follicles $=\geq 2$ to $3 \mathrm{~mm}$; medium follicles $=>3$ to $<5 \mathrm{~mm}$; large ovulatory follicles $=>5$ $\mathrm{mm}$ ) in each doe (Hashem et al., 2015), was recorded on d 0, 14, 28, and 42 (before CIDR insertion), d 61(CIDR removal), and d 63 (mating). The diameter of the largest (ovulatory) follicle and numbers and diameters of corpora lutea were also recorded. Pregnancy diagnosis was recorded by scanning the uterine contents at $\mathrm{d} 28$ and 56 postmating.

\section{Reproductive Performance}

Reproductive performance was calculated using the following formulas:

estrus rate $=$ no. of does displaying estrus $/$ no. of synchronized does $\times 100$,

conception rate $(\mathrm{d} 18)=[$ no. of does conceiving on d 18 (based on $\mathrm{P}_{4}$ concentration of $2.5 \mathrm{ng} / \mathrm{mL}$ )/ no. of exposed does] $\times 100$ (Boscos et al., 2003), conception rate $(\mathrm{d} 28$ and 56$)=[$ no. of does conceiving on d 28 and 56 (based on ultrasonography)/no. of exposed does] $\times 100$, prolificacy $=$ no. of fetuses $/$ pregnant does, fecundity $=$ (no. of fetuses/no. of exposed does $)$

$$
\times 100 \text {. }
$$

\section{Hormonal Assays}

Morning blood samples were collected in $10-\mathrm{mL}$ silicon-coated evacuated tubes (Becton Dickinson, Franklin Lakes, NJ) from the jugular vein of each doe before access to feed and water on d $0,14,28$, and 42 before CIDR insertion; day of CIDR removal (d 61); day of mating (d 63); and d 18, 28, and 56 after mating for pregnancy diagnosis. Serum was obtained by centrifugation of samples at $2,000 \times g$ for $20 \mathrm{~min}$ at $4^{\circ} \mathrm{C}$, collected, and stored at $-20^{\circ} \mathrm{C}$ until analyses. Blood serum concentration of $\mathrm{P}_{4}$ was measured using solid-phase enzyme immunoassay kits obtained from Monobind Inc. (Lake Forest, CA). The lower limit of detection was $0.11 \mathrm{ng} / \mathrm{mL}$, and the intra- and interassay coefficients of variation were $9.3 \%$ and $9.9 \%$, respectively. Blood serum concentration of estradiol $\left(\mathbf{E}_{2}\right)$ was measured using solid-phase enzyme immunoassay kits obtained from Monobind Inc. (Lake Forest, CA). The lower limit of detection was $8.2 \mathrm{pg} / \mathrm{mL}$, and the intra- and interassay coefficients of variation were $9.9 \%$ and $8.2 \%$, respectively. In addition, $\mathrm{E}_{2}: \mathrm{P}_{4}$ ratio was calculated.

\section{Statistical Analysis}

All data records were tested for normality with the Shapiro-Wilk test from the UNIVARIATE procedure 
of SAS (SAS Institute Inc., Cary, NC), and results indicated that all data were distributed normally $(\mathrm{W} \geq$ 0.90). To avoid the heterogeneity of error if it existed, all percentage data records greater than $10 \%$ were transformed to their corresponding arcsine angles according to Steel and Torrie (1980). Data for the effect of melatonin were analyzed using the MIXED procedure of SAS for repeated measures. Treatment, physiological status, and days were used as fixed effects, and individual does were used as random effects. Data for the effect of melatonin on ovarian activity and hormonal level were analyzed by adapting the following model:

$$
\begin{aligned}
Y_{i j k l}= & \mu+T_{i}+P_{j}+D_{k}+(T \times P)_{i j}+(T \times D)_{i k} \\
& +(P \times D)_{j k}+(T \times P \times D)_{i j k}+e_{i j k l},
\end{aligned}
$$

where $Y_{i j k l}$ is the observed value of the dependent variable determined from a sample taken from each animal; $\mu$ is the overall mean; $T_{i}$ is the fixed effect of the $i$ th treatment $(i=1: 2) ; P_{j}$ is the fixed effect of the $j$ th physiological status, dry and lactating $(j=1: 2) ; D_{k}$ is the fixed effect of the $k$ th day for ovarian activity $(k=0: 63)$ and for hormonal assays $(k=0: 119) ;(T$ $\times P)_{i j}$ is the first-order interaction between treatment and physiological status; $(T \times D)_{i k}$ is the first-order interaction between treatment and day; $(P \times D)_{j k}$ is the first-order interaction between physiological status and day; $(T \times P \times D)_{i j k}$ is the second-order interaction among treatment, physiological status, and day; and $e_{i j k l}$ is the residual error. Significant differences among means within each classification were tested using least significant differences (LSD at $P<0.05$ ). The data of reproductive performance parameters were analyzed using the chi-squared test. A $95 \%$ confidence interval was used.

\section{RESULTS AND DISCUSSION}

\section{Effect of Hormonal Treatments on Ovarian Activity and Hormonal Levels}

CIDR and CIDR Preceded with Melatonin. The improvement of luteal function in the present study (Table 1) was expressed as greater numbers of corpora lutea $(P=0.022)$ and serum $\mathrm{P}_{4}$ concentration $(P=$ 0.038 ) in the melatonin-implanted does compared with the nonimplanted does, which is consistent with results reported in sheep (Abecia et al., 2002, 2006). Melatonin appears to act at hypothalamic sites to increase the release of pulses of GnRH by modulating the negative feedback potency of $E_{2}$ (Noël et al., 1999), which acts at hypothalamic and pituitary loci to reduce luteinizing hormone secretion (Caraty et al., 1989). Furthermore, melatonin acts directly on the corpus luteum to increase $\mathrm{P}_{4}$ production (Durotoye et al., 1997; Abecia et al., 2002) rather than via decreasing uterine secretion of $\mathrm{PGF}_{2 \alpha}$ (Gimeno et al., 1980a) and modifying $\mathrm{PGF}_{2 \alpha}$ biosynthesis in the hypothalamus (Bojanowska and Forsling, 1997). In addition, the increasing number of corpora lutea could be attributable to the suppressing effect of melatonin on prolactin concentration in goats (Yue et al., 2010), where the elevated prolactin concentrations are thought to have negative or inhibitory effects on reproduction (Kann and Martinet, 1975). The reducing effect of melatonin on $\mathrm{E}_{2}$ concentration has been reported previously (Noël et al., 1999) and is clearly indicated in the present study (Table 1). Moreover, melatonin decreases $\mathrm{E}_{2}$ receptor expression in the deep stroma of ewes where the $\mathrm{E}_{2}$ receptor complex acts as a luteolytic agent (Vázquez et al., 2013), and $\mathrm{E}_{2}$ concentration has been correlated with the mean response of $\mathrm{PGF}_{2 \alpha}$ to oxytocin via the estrogenic stimulation of uterine oxytocin receptors (Beard and Lamming, 1994).

Physiological Status of Does. The decrease $(P=$ 0.011) of serum $\mathrm{P}_{4}$ concentration in lactating compared with dry does (Table 2) is suggested to be attributable to the effect of prolactin. Misztal et al. (1997) reported that, during the lactation period, melatonin concentration decreases and prolactin (a hormone responsible for the initiation and maintenance of lactation) increases. Furthermore, suckling is an important factor that stimulates prolactin secretion in nursing dams (Grattan, 2002). On the other hand, studies on drying-off management found that prolactin secretion was inhibited during the drying-off period (Ollier et al., 2013). Prolactin may block the hypothalamic mechanism responsible for episodic release of $\mathrm{LH}$ or inhibit the positive feedback of estrogen on LH secretion. It may also affect ovarian steroidogenesis by altering the number of LH receptors (Sheth et al., 1978). Furthermore, lactating does that were not implanted exhibited the lowest numbers of corpora lutea $(P=0.010)$ compared with other groups (Figure 2). These findings recognized the proper effect of melatonin on both dry and lactating does. The ability of melatonin to counteract the detrimental effect of prolactin was expressed as a greater number of corpora lutea in lactating implanted does compared with nonimplanted does. However, in the absence of a detrimental effect of prolactin (in dry does), the number of corpora lutea was not affected by melatonin implantation. Furthermore, melatonin implantation successfully makes the number of corpora lutea observed in lactating does comparable with that observed in dry does.

Days of Treatment. With the advancement of day of treatment, all ovarian activities were affected $(P<$ 0.001) except the diameters of the largest follicles and 
Table 1. Effect of controlled internal drug release (CIDR) and CIDR preceded with melatonin (Mel + CIDR) treatments on ovarian activity and hormonal levels of Anglo-Nubian does during the nonbreeding season (least squares means \pm SEM)

\begin{tabular}{|c|c|c|c|c|c|c|}
\hline \multirow[b]{2}{*}{ Parameter } & \multicolumn{2}{|c|}{ Treatment } & \multirow[b]{2}{*}{ SEM } & \multicolumn{3}{|c|}{$P$-value } \\
\hline & CIDR & $\mathrm{Mel}+\mathrm{CIDR}$ & & Treatment & Days & $\begin{array}{l}\text { Treatment } \\
\times \text { days }\end{array}$ \\
\hline \multicolumn{7}{|l|}{ Ovarian activity } \\
\hline Follicles/doe, no. & 3.20 & 3.24 & 0.11 & 0.835 & 0.001 & 0.179 \\
\hline \multicolumn{7}{|l|}{ Follicular population, no. } \\
\hline Small follicles, $\geq 2$ to $3 \mathrm{~mm}$ & 1.28 & 1.17 & 0.10 & 0.503 & 0.001 & 0.071 \\
\hline Medium follicles, $>3$ to $<5 \mathrm{~mm}$ & 1.09 & 1.13 & 0.09 & 0.750 & 0.001 & 0.394 \\
\hline Large follicles, $>5 \mathrm{~mm}$ & 0.84 & 0.95 & 0.07 & 0.291 & 0.001 & 0.001 \\
\hline Diameter of largest follicles, $\mathrm{mm}$ & 5.97 & 5.92 & 0.08 & 0.201 & 0.406 & 0.259 \\
\hline Corpora lutea, no. & $0.34^{\mathrm{b}}$ & $0.48^{\mathrm{a}}$ & 0.04 & 0.022 & 0.001 & 0.001 \\
\hline Diameter of corpus luteum, mm & 9.88 & 9.71 & 0.17 & 0.250 & 0.412 & 0.807 \\
\hline \multicolumn{7}{|l|}{ Hormone levels } \\
\hline Progesterone, $\mathrm{ng} / \mathrm{mL}$ & $2.02^{\mathrm{b}}$ & $2.99^{\mathrm{a}}$ & 0.33 & 0.038 & 0.001 & 0.372 \\
\hline Estradiol, $\mathrm{pg} / \mathrm{mL}$ & $57.42^{\mathrm{a}}$ & $44.76^{\mathrm{b}}$ & 2.25 & 0.001 & 0.037 & 0.370 \\
\hline Estradiol:progesterone ratio & 0.18 & 0.15 & 0.02 & 0.449 & 0.001 & 0.792 \\
\hline
\end{tabular}

${ }^{\mathrm{a}, \mathrm{b}}$ Means within a row with different superscripts differ $(P<0.05)$.

corpora lutea (Table 3). Based on these results, we suggested the developmental capacity of ovarian activity with advancement of day of treatment to be caused by antagonism between melatonin and prolactin. The greatest $(P<0.001)$ value of total number of follicles observed at d 42 and 63 (Table 3 ) could be attributed to different mechanisms. At d 42, the greatest total number of follicles resulted from the greatest number of both small and medium follicles but not large follicles. This seems to reflect the atretic effect of prolactin on both small and medium follicles, as the prolactin gene has been reported to show increased small follicles and impaired oocyte maturation (Parks, 2004). This could explain the reduction $(P<0.001)$ in the number of large follicles of the nonimplanted does compared with the melatonin-implanted does at d 42 (Figure 3, upper panel). In addition, Prandi et al. (1987) reported the beneficial effect of melatonin on reducing prolactin concentration in melatonin-treated goats during the anestrus season. On the other hand, the greatest $(P<$ 0.001 ) total number of follicles at $d 63$ resulted from the greatest number of large follicles but not small and medium follicles (Table 3). This improvement is confirmed by the greatest $(P<0.001)$ total number of follicles in dry does compared with lactating does at d 63 (Figure 4, upper panel); this could be caused by the lack of the atretic effect of prolactin in dry does, which allows the beneficial effect of melatonin to take place. Moreover, the increasing number of total follicles at d 63 (day of estrus) could be attributable to eCG administration (at d 61), which increases the number of large ovarian follicles at estrus (Noël et al., 1994). Equine chorionic gonadotropin enhances the entry of small and medium follicles into large follicles and prevents the occurrence of natural follicular atresia (Bister et al., 1999). In addition, the number of small follicles decreased following eCG treatment and reached a lower $(P<0.001)$ value at estrus (d 63; Table 3); this has been reported previously in ewes (Kermani Moakhar et al., 2012). Collectively, these findings could confirm the present results (Table 3 ) in which at d 63 both small and medium follicles were reduced but the large follicles were increased $(P<0.001)$. On the other hand, the reduced $(P<$ 0.001 ) number of large follicles at d 61 (CIDR removal) has been reported previously (Honparkhe et al., 2011). The number of corpora lutea tended to increase $(P<$ 0.001) throughout d 14 to 42 (Table 3), indicating the luteotrophic effect of melatonin and showing the ability of melatonin to counteract the detrimental effect of prolactin. At d 14, the luteotrophic effect of melatonin takes place in the absence of the detrimental effect of prolactin (Figure 4, lower panel), where the greatest

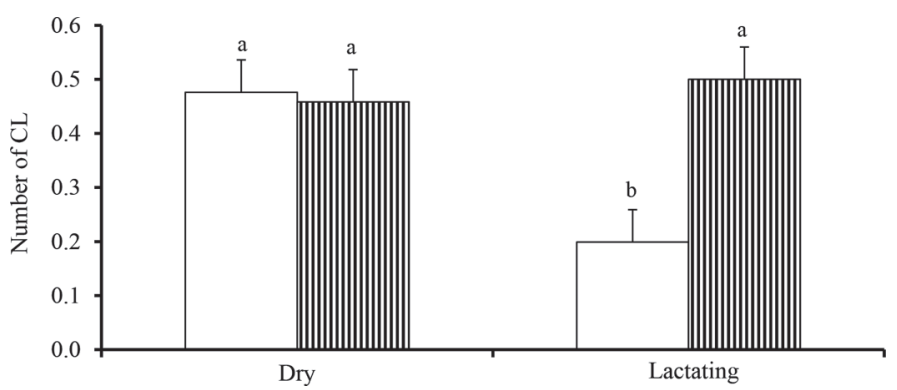

Figure 2. Changes in number of corpora lutea (CL) in controlled internal drug release (CIDR, white bars) and CIDR preceded with melatonin treatments (shaded bars) of dry and lactating Anglo-Nubian does during the nonbreeding season. Values with different letters $(\mathrm{a}, \mathrm{b})$ differ $(P=0.010)$. Error bars represent SEM. 
Table 2. Effect of physiological status on ovarian activity and hormonal levels of Anglo-Nubian does after controlled internal drug release (CIDR) and CIDR preceded with melatonin treatments during the nonbreeding season (least squares means \pm SEM)

\begin{tabular}{|c|c|c|c|c|c|c|c|c|}
\hline \multirow[b]{2}{*}{ Parameter } & \multicolumn{2}{|c|}{ Status } & \multirow[b]{2}{*}{ SEM } & \multicolumn{5}{|c|}{$P$-value } \\
\hline & Dry & Lactating & & Status & Days & Treatment & $\underset{\text { days }}{\text { Status }} \times$ & $\begin{array}{l}\text { Status } \times \\
\text { treatment }\end{array}$ \\
\hline \multicolumn{9}{|l|}{ Ovarian activity } \\
\hline Follicles/doe, no. & 3.31 & 3.13 & 0.11 & 0.262 & 0.001 & 0.835 & 0.010 & 0.966 \\
\hline \multicolumn{9}{|l|}{ Follicular population, no. } \\
\hline Small follicles, $\geq 2$ to $3 \mathrm{~mm}$ & 1.21 & 1.23 & 0.10 & 0.907 & 0.001 & 0.503 & 0.153 & 0.294 \\
\hline Diameter of largest follicles, $\mathrm{mm}$ & 6.05 & 5.95 & 0.09 & 0.178 & 0.406 & 0.201 & 0.344 & 0.395 \\
\hline Corpora lutea, no. & 0.47 & 0.35 & 0.04 & 0.056 & 0.001 & 0.022 & 0.050 & 0.010 \\
\hline Diameter of corpus luteum, mm & 9.69 & 9.78 & 0.18 & 0.196 & 0.412 & 0.250 & 0.292 & 0.874 \\
\hline \multicolumn{9}{|l|}{ Hormone levels } \\
\hline Progesterone, ng/mL & $3.10^{\mathrm{a}}$ & $1.91^{\mathrm{b}}$ & 0.33 & 0.011 & 0.001 & 0.038 & 0.582 & 0.940 \\
\hline Estradiol, $\mathrm{pg} / \mathrm{mL}$ & 49.46 & 52.72 & 2.25 & 0.307 & 0.037 & 0.001 & 0.051 & 0.474 \\
\hline Estradiol:progesterone ratio & 0.17 & 0.16 & 0.02 & 0.881 & 0.001 & 0.449 & 0.386 & 0.164 \\
\hline
\end{tabular}

${ }^{\mathrm{a}, \mathrm{b}}$ Means within a row with different superscripts differ $(P<0.05)$.

$(P=0.050)$ numbers of corpora lutea were recorded in dry does compared with lactating does (regardless of melatonin implantation). On the other hand, at d 42 , a greater $(P<0.001)$ number of corpora lutea were recorded in melatonin-implanted does compared with nonimplanted does (regardless of physiological status), as presented in Figure 3 (lower panel).

In addition, serum concentrations of $\mathrm{P}_{4}$ and $\mathrm{E}_{2}$ and their ratio were affected $(P<0.001, P=0.037$, and $P<0.001$, respectively) throughout the experiment, which lasted $119 \mathrm{~d}$ (Table 4). Serum $\mathrm{P}_{4}$ concentration recorded the lowest $(P<0.001)$ values from d 0 to 63 (day of mating) and the greatest $(P<0.001)$ values at $\mathrm{d}$ 81, 91, and 119 of the experiment, representing d 18 (hormonal pregnancy diagnosis), d 28, and d 56 (ultrasonography pregnancy diagnosis) after mating. On the other hand, the $\mathrm{E}_{2}: \mathrm{P}_{4}$ ratio was greater $(P<$ 0.001 ) at $\mathrm{d} 0,42$, and 63 (day of mating) and lower
$(P<0.001)$ throughout days of pregnancy diagnosis. Interestingly, the higher $(P=0.037)$ value of serum $\mathrm{E}_{2}$ concentration recorded at day of mating (d 63) did not differ significantly from values observed throughout the pregnancy period (at d 81, 91, and 119 representing d 18,28 , and 56 after mating). Changes in steroidogenic activity with increasing experimental day (Table 4) indicated an association of low $\mathrm{P}_{4}$ concentration until d 42 with the greatest numbers of corpora lutea (Table 3). This conflict could indicate the occurrence of abnormal luteal activity, which has been reported during the nonbreeding season (Atkinson, 1988). However, melatonin implantation tended to increase serum $\mathrm{P}_{4}$ concentration (Table 1) and number of corpora lutea until d 42 (Figure 3, lower panel). Furthermore, there was a tendency of increasing serum $\mathrm{E}_{2}$ concentration (Table 4) associated with an increase in the number of large follicles until d 42 (Table 3 ). This seems to

Table 3. Effect of day after controlled internal drug release (CIDR) and CIDR preceded with melatonin treatments on ovarian activity of AngloNubian does during the nonbreeding season (least squares means \pm SEM)

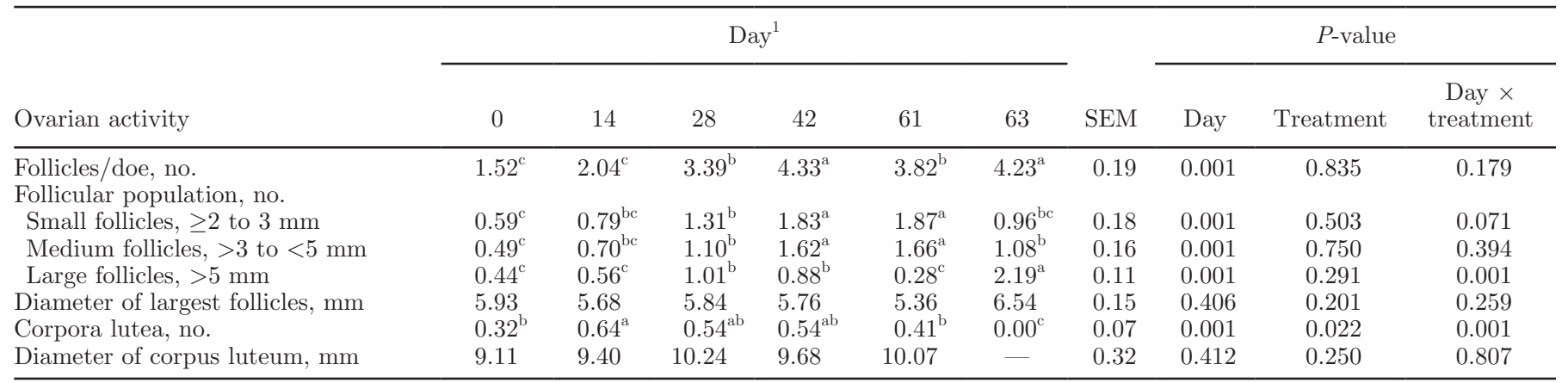

\footnotetext{
${ }^{\mathrm{a}-\mathrm{c}}$ Means within a row with different superscripts differ $(P<0.05)$.

${ }^{1}$ Day $0=$ melatonin implantation in treated groups; $\mathrm{d} 42=\mathrm{CIDR}$ insertion in control and treated groups; $\mathrm{d} 61=\mathrm{CIDR}$ removal and equine chorionic gonadotropin injection; d 63 = mating.
} 
be attributable to melatonin implantation, where the number of large follicles tended to increase to record the greatest value at d 42 in melatonin-implanted does (Figure 3, upper panel). After CIDR removal, serum $\mathrm{P}_{4}$ concentration decreased $(P<0.001)$ at d 63 (day of estrus), which has been reported previously in does (Menchaca et al., 2007; Rowe et al., 2010; Souza et al., 2011). In addition, $\mathrm{P}_{4}$ concentration has been reported to be lowest on the day of estrus (Mondal et al., 2006). This low $\mathrm{P}_{4}$ concentration is a necessary prerequisite to the expression of estrus because $\mathrm{P}_{4}$ is clearly inhibitory to estrus behavior in ewes (Fabre-Nys and Martin, 1991). The greatest $(P<0.001)$ values of $\mathrm{P}_{4}$ concentration throughout days of pregnancy diagnosis (d 81, 91, and 119) indicated the beneficial effect of hormonal treatment $\left(\mathrm{P}_{4}\right.$ and $\left.\mathrm{eCG}\right)$ on pregnancy rate, which has been reported previously (Kaya et al., 2013). Progesterone is administered before ovulation to inhibit oxytocin receptors in the endometrium, thus reducing the uterine response to oxytocin for the secretion of $\mathrm{PGF}_{2 \alpha}$ (Leyva et al., 1998). Administration of eCG in ewes during the anestrus period aids corpora lutea development and helps increase the secretion of $\mathrm{P}_{4}$ (Fukui et al., 2001). The greater $(P<0.001)$ value of $\mathrm{E}_{2}: \mathrm{P}_{4}$ ratio was recorded on the day of estrus that was associated with the lowest concentration of $\mathrm{P}_{4}$ (Table 4); this
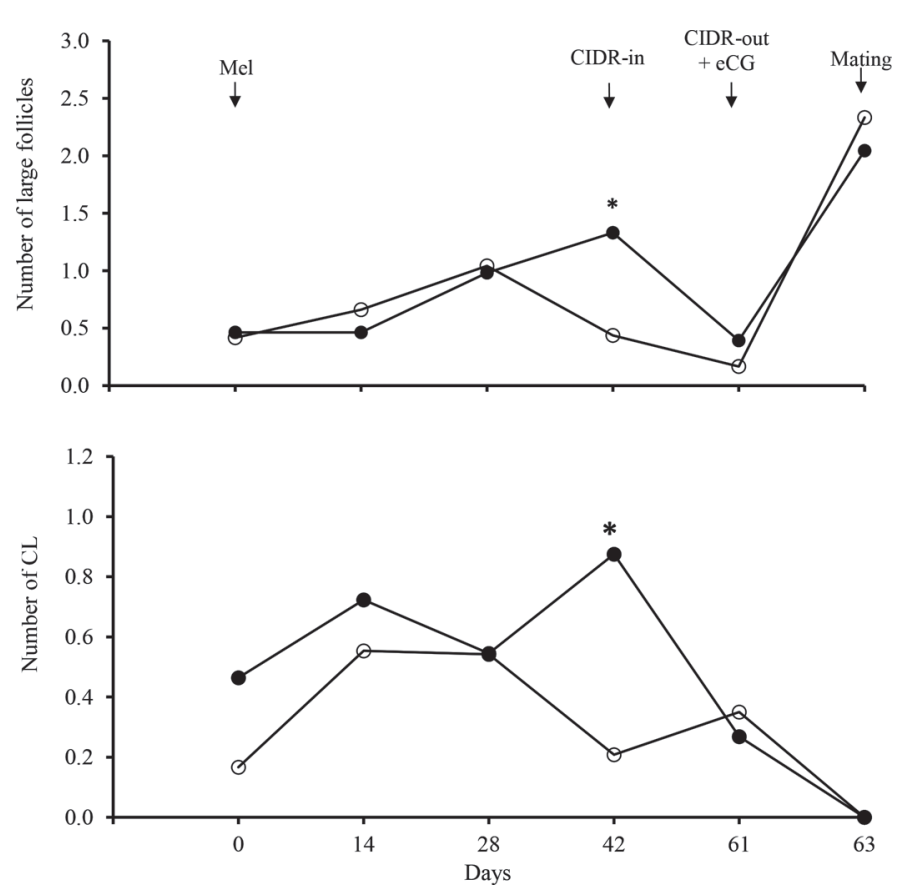

Figure 3. Changes in the number of large follicles (upper panel) and the number of corpora lutea (CL; lower panel) in Anglo-Nubian does treated with controlled internal drug release (CIDR, O) and CIDR preceded with melatonin ( $\mathrm{Mel}, \bullet)$ during the nonbreeding season. $\mathrm{eCG}=$ equine chorionic gonadotropin. ${ }^{*}$ Treatments differ within a time point $(P<0.05)$. provides compelling evidence that detection of onset of estrus was accurate (Sullivan et al., 2013). On the other hand, the lower $\mathrm{E}_{2}: \mathrm{P}_{4}$ ratio values recorded on days of pregnancy diagnosis (d 81, 91, and 119 representing d 18,28 , and 56 of pregnancy) were associated with the greatest values of serum $\mathrm{P}_{4}$ concentration. These low values of $\mathrm{E}_{2}: \mathrm{P}_{4}$ ratio indicated the success of maternal recognition of pregnancy; the high $\mathrm{E}_{2}: \mathrm{P}_{4}$ ratio in early pregnancy may generate larger $\mathrm{PGF}_{2 \alpha}$ episodes, which increase the risk of failure of maternal recognition of pregnancy (Abecia et al., 2003). Interestingly, however, $\mathrm{E}_{2}: \mathrm{P}_{4}$ ratio was lower at d 119 (d 56 of pregnancy), but it was associated with the greatest value of serum $E_{2}$ concentration. The increasing $\mathrm{E}_{2}$ concentration seems to be responsible for embryonic loss observed at this stage of pregnancy, which is discussed later.

\section{Effect of Hormonal Treatments on Reproductive Performance}

Melatonin implantation failed to induce estrus signs during the first $42 \mathrm{~d}$ of the present experiment. However, $48 \mathrm{~h}$ after CIDR removal and eCG injection, estrus rate was $100 \%$ for implanted and nonimplanted does (Table 5). Our results are in accordance with the
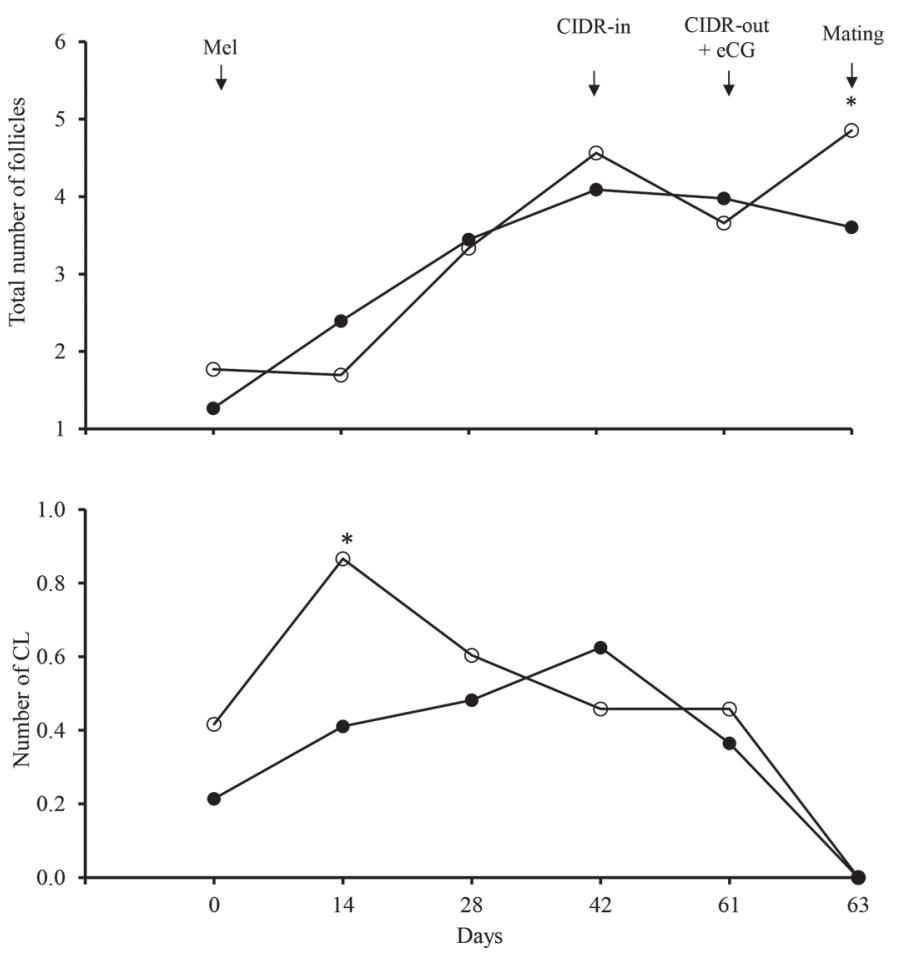

Figure 4. Changes in the total number of follicles (upper panel) and the number of corpora lutea (CL; lower panel) in dry $(O)$ and lactating (๑) Anglo-Nubian does during the nonbreeding season. eCG $=$ equine chorionic gonadotropin. ${ }^{*}$ Treatments differ within a time point $(P<0.05)$. 
findings reported by Blaszczyk et al. (2004) in AngloNubian goats treated with $\mathrm{P}_{4}-\mathrm{eCG}$, which resulted in $100 \%$ does being in estrus, as well as those of Ramukhithi et al. (2012) and Contreras-Villarreal et al. (2016), who were able to induce estrus in goats outside the breeding season. This indicates that the incidence of estrus behavior in the present study was not attributable to the melatonin effect, which could be explained by the present observations that Anglo-Nubian does are long-day breeders. Similarly, deNicolo et al. (2008) reported that melatonin was ineffective in inducing out-of-season reproductive activity in sheep. In addition, estrus response did not differ between dry and lactating does, as reported previously (Fonseca et al., 2008). It is worth noting that does that come to heat by $\mathrm{P}_{4}-\mathrm{eCG}$ treatment show only 1 estrus, and if they do not conceive they do not come to heat again (Abecia et al., 2011).

The present study indicated that a $\mathrm{P}_{4}$-eCG protocol was effective for inducing estrus and ovulation in goats during the nonbreeding season, which has been reported previously (Contreras-Villarreal et al., 2016). In addition, the $\mathrm{P}_{4}$-eCG protocol succeeded in achieving a $58.33 \%$ conception rate, 2.00 prolificacy, and $33.33 \%$ fecundity (Table 5). Furthermore, in conjunction with $\mathrm{P}_{4}$ eCG, reproductive performance was enhanced by melatonin implantation, which resulted in a greater $(P$ $=0.027)$ conception rate and fecundity $(P=0.039)$ at $\mathrm{d}$ 28 of pregnancy as reported in goats (Celi et al., 2013) and prolificacy $(P<0.001)$ at d 56 compared with nonimplanted does (Table 5). The improvement of reproductive performance using a $\mathrm{P}_{4}$-eCG protocol indicates its beneficial effect on reproduction. Equine chorionic gonadotropin helps the oocyte mature (Schmitt et al., 1996) and could generate increases in $\mathrm{E}_{2}-17 \beta$, promoting the LH surge and in turn inducing ovulation in most goats (Menchaca et al., 2007). However, secretion of gonadotropin is insufficient during the preovulatory phase during the nonbreeding season; thus, fully functional corpora lutea does not occur and $\mathrm{P}_{4}$ secretion is insufficient (Spencer et al., 2004). Hence, administering eCG in $\mathrm{P}_{4}$-treated ewes during the nonbreeding season had a positive effect on pregnancy rates (Kaya et al., 2013). It has been reported that eCG helps the blastocyst to develop and downregulates $\mathrm{E}_{2}$ and oxytocin, thus strongly suppressing the secretion of $\mathrm{PGF}_{2 \alpha}$ and causing the blastocyst to secrete more interferon-tau (Nephew et al., 1994). This causes the conceptus to grow and leads to significant increases in placentation (Khan et al., 2003).

Melatonin receptors are expressed in antral follicles and the corpus luteum, which may influence ovarian follicular dynamics and intraovarian endocrine interactions (Baratta and Tamanini, 1992). In addition, mela- 
Table 5. Effect of controlled internal drug release (CIDR) and CIDR preceded with melatonin (Mel + CIDR) treatments on reproductive performance of Anglo-Nubian does during the nonbreeding season (least squares means)

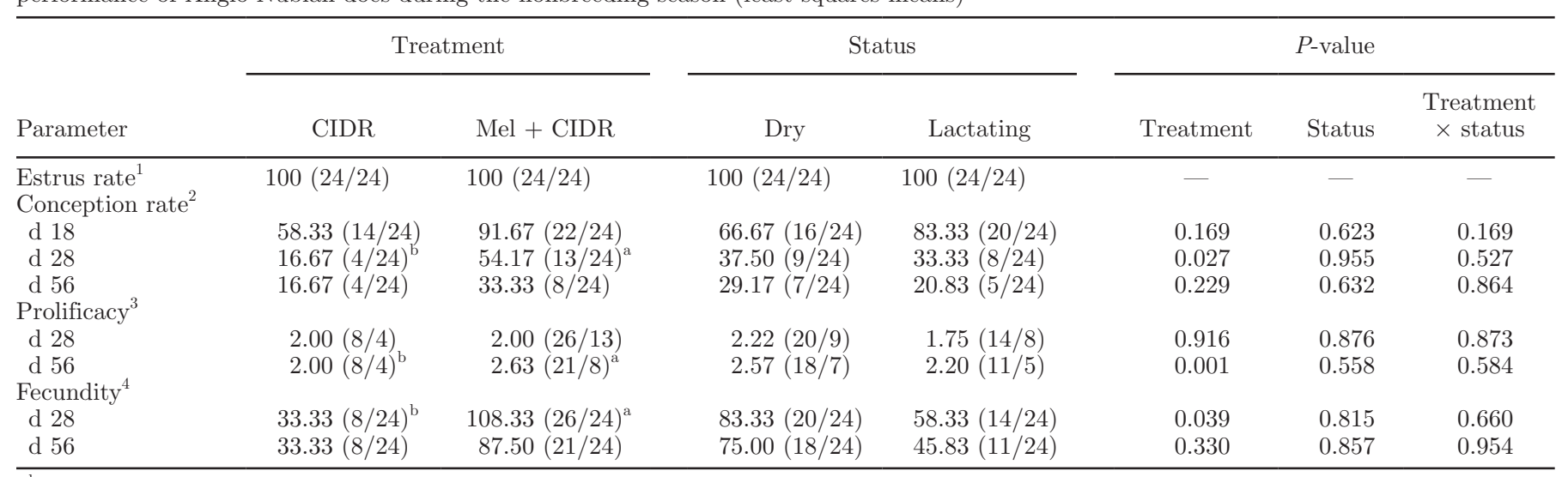

${ }_{\mathrm{a}, \mathrm{b}}$ Means within a row with different superscripts differ $(P<0.05)$.

${ }^{1}$ Estrus rate $=($ no. of does displaying estrus/no. of synchronized does $) \times 100$.

${ }^{2}$ Conception rate on d $18=$ [no. of does conceiving on d 18 (based on progesterone concentration of $2.5 \mathrm{ng} / \mathrm{mL}$ ) $/ \mathrm{no}$. of exposed does] $\times 100$. Conception rate on d 28 and $56=$ [no. of does conceiving on d 28 and 56 (based on ultrasonography)/no. of exposed does] $\times 100$.

${ }^{3}$ Prolificacy $=$ no. of fetuses $/$ no. of pregnant does.

${ }^{4}$ Fecundity $=$ (no. of fetuses/no. of exposed does $) \times 100$.

tonin improves developmental oocyte competence in the seasonal anestrus period (Vázquez et al., 2010) and significantly increases the maturation rate of oocytes and tends to increase their cleavage rate (Casao et al., 2010). Also, melatonin reduces embryo degeneration (Buffoni et al., 2014) and increases the percentage of hatched blastocysts (Abecia et al., 2002) during seasonal anestrus. Furthermore, the luteotrophic effect of melatonin has been reported (Durotoye et al., 1997), leading to an increase in plasma $\mathrm{P}_{4}$ concentrations. Increasing plasma $\mathrm{P}_{4}$ concentrations modifies the embryo-mother relationship by stimulating changes in the physiological state of the uterus sufficiently to influence embryo survival (Lawson and Cahill, 1983). The action of estrogens and $\mathrm{P}_{4}$ in the uterus is mediated through interactions with their intracellular receptors (estrogen receptor, ER; progesterone receptor, PR; Clark et al., 1992). Melatonin implantation resulted in an increment of the expression of PR in the deep glandular epithelium and a decrease of ER in the deep stroma of ewes (Vázquez et al., 2013). Melatonin increases the sensitivity to $\mathrm{P}_{4}$ because this hormone enhances the differentiation of the epithelia and, thereby, the secretory function of the endometrium (Cunha et al., 2004). On the other hand, melatonin decreases ER $\alpha$ expression in the deep stroma of ewes. The $\mathrm{E}_{2}$-ER $\alpha$ complex acts as a luteolytic agent; thus, a decrease in estrogen sensitivity (ER $\alpha$ content) in the deep stroma is consistent with the possible beneficial effects of melatonin in the uterine preparation for pregnancy, as observed for the PR receptor (Vázquez et al., 2013).
The effect of exogenous melatonin on the establishment of pregnancy and on embryo development is expressed as blocking the in vitro generation of $\mathrm{PGF}_{2 \alpha}$ by the uterus (Gimeno et al., 1980b) and modifying $\mathrm{PGF}_{2 \alpha}$ biosynthesis in the hypothalamus (Bojanowska and Forsling, 1997). A successful blockage of endometrial $\mathrm{PGF}_{2 \alpha}$ production has a vital role in the maintenance of pregnancy. Blocking luteolysis is dependent on the ability of the conceptus to send effective antiluteolytic signals (interferon-tau) and on the capacity of the endometrium to respond to such signals, thus blocking $\mathrm{PGF}_{2 \alpha}$ production. Disturbance of these embryo-mother interactions can result in embryonic loss (Jerome and Srivastava, 2012). The presence of an early $\mathrm{P}_{4}$ peak (after mating) facilitates the elongation of the conceptus and, consequently, the secretion of adequate interferon-tau (Mann, 2002). Interferon-tau extends the life span of the corpus luteum (Plante et al., 1989) by suppressing $\mathrm{E}_{2}$ receptor and oxytocin receptor genes in sheep (Spencer and Bazer, 1996) and by attenuating the endometrial secretion of $\mathrm{PGF}_{2 \alpha}$ (Helmer et al., 1989). Interestingly, a reduction in conception rate has been observed with the advancement of day of pregnancy (throughout d 18, 28, and 56) in the present study (Table 5). This finding could be attributable to the greatest $(P=0.037) \mathrm{E}_{2}$ concentration at $\mathrm{d} 56$ of pregnancy (Table 4). This high level of $\mathrm{E}_{2}$ results in the upregulation of endometrial oxytocin receptors, which tend toward the premature release of $\mathrm{PGF}_{2 \alpha}$ from the uterus, leading to subnormal luteal function (Ishwar and Memon, 1996). 
In conclusion, a CIDR-eCG protocol successfully achieved fertile estrus during the nonbreeding season in Anglo-Nubian does. Furthermore, melatonin implantation in conjunction with the CIDR-eCG protocol increased conception rate, fecundity, and prolificacy compared with nonimplanted does. The current study presented a melatonin-CIDR-eCG protocol as a feasible option for improving reproductive performance during the nonbreeding season in goats.

\section{ACKNOWLEDGMENTS}

This research was funded by Animal Production Department, Faculty of Agriculture (El-Shatby), Alexandria University, Alexandria, Egypt. The authors thank M. El-Tourky, the former Dean of Faculty of Agriculture (El-Shatby), for his valuable support. The authors also thank Ahmed Mostafa and Galal Sayed for their technical assistance.

\section{REFERENCES}

Abecia, J. A., F. Fernando, J. Valaresa, O. Zúñiga, and H. Kindahl. 2003. Effect of exogenous melatonin on in vivo and in vitro prostaglandin secretion in Rasa Aragonesa ewes. Theriogenology 60:1345-1355. https://doi.org/10.1016/s0093-691x(03)00168-7.

Abecia, J. A., F. Forcada, and A. González-Bulnes. 2011. Pharmaceutical control of reproduction in sheep and goats. Vet. Clin. North Am. Food Anim. Pract. 27:67-79. https://doi.org/10.1016/j. cvfa.2010.10.001.

Abecia, J. A., F. Forcada, and O. Zuñiga. 2002. The effect of melatonin on the secretion of progesterone in sheep and on the development of ovine embryos in vitro. Vet. Res. Commun. 26:151-158. https://doi.org/10.1023/a:1014099719034.

Abecia, J. A., I. Palacin, F. Forcada, and J. Valares. 2006. The effect of melatonin treatment on the ovarian response of ewes to the ram effect. Domest. Anim. Endocrinol. 31:52-62. https://doi. org/10.1016/j.domaniend.2005.09.003.

AOAC (Association of Official Analytical Chemists). 1984. Official Methods of Analysis. 14th ed. Association of Official Analytical Chemists, Arlington, VA.

Atkinson, S. 1988. Inadequate function of corpora lutea following the induction of ovulation with monensin and FSH in seasonally anestrous ewes. J. Endocrinol. 117:167-172. https://doi.org/10.1677/ joe.0.1170167.

Baratta, M., and C. Tamanini. 1992. Effect of melatonin on the in vitro secretion of progesterone and estradiol $17 \beta$ by ovine granulosa cells. Acta Endocrinol. (Copenh.) 127:366-370. https://doi. org/10.1530/acta.0.1270366.

Beard, A. P., and G. Lamming. 1994. Oestradiol concentration and the development of the uterine oxytocin receptor and oxytocininduced PGF2a release in ewes. J. Reprod. Fertil. 100:469-475. https://doi.org/10.1530/jrf.0.1000469.

Bedos, M., G. Duarte, J. Flores, G. Fitz-Rodríguez, H. Hernández, J. Vielma, I. Fernández, P. Chemineau, M. Keller, and J. Delgadillo. 2014. Two or $24 \mathrm{~h}$ of daily contact with sexually active males results in different profiles of LH secretion that both lead to ovulation in anestrous goats. Domest. Anim. Endocrinol. 48:93-99. https://doi.org/10.1016/j.domaniend.2014.02.003.

Berlinguer, F., G. Leoni, S. Succu, A. Spezzigu, M. Madeddu, V. Satta, D. Bebbere, I. Contreras-Solis, A. Gonzalez-Bulnes, and S. Naitana. 2009. Exogenous melatonin positively influences follicular dynamics, oocyte developmental competence and blastocyst output in a goat model. J. Pineal Res. 46:383-391. https://doi. org/10.1111/j.1600-079X.2009.00674.x.

Bister, J. L., B. Noël, B. Perrad, S. Mandiki, J. Mbayahaga, and R. Paquay. 1999. Control of ovarian follicle activity in the ewe. Domest. Anim. Endocrinol. 17:315-328. https://doi.org/10.1016/ s0739-7240(99)00047-8.

Blaszczyk, B., J. Udala, and D. Gączarzewicz. 2004. Changes in estradiol, progesterone, melatonin, prolactin and thyroxin concentrations in blood plasma of goats following induced estrus in and outside the natural breeding season. Small Rumin. Res. 51:209-219. https://doi.org/10.1016/s0921-4488(03)00190-1.

Bojanowska, E., and M. Forsling. 1997. The effects of melatonin on vasopressin secretion in vivo: Interactions with acetylcholine and prostaglandins. Brain Res. Bull. 42:457-461. https://doi. org/10.1016/s0361-9230(96)00372-3.

Boscos, C. M., F. Samartzi, A. Lymberopoulos, A. Stefanakis, and S. Belibasaki. 2003. Assessment of progesterone concentration using enzyme immunoassay, for early pregnancy diagnosis in sheep and goats. Reprod. Domest. Anim. 38:170-174. https://doi. org/10.1046/j.1439-0531.2003.00407.x.

Buffoni, A., P. Vozzi, D. Gonzalez, G. Rios, H. Viegas-Bordeira, and J. Abecia. 2014. The effect of melatonin and season on in vivo embryo production of Dohne Merino ewes. Small Rumin. Res. 120:121-124. https://doi.org/10.1016/j.smallrumres.2014.05.003.

Caraty, A., A. Locatelli, and G. Martin. 1989. Biphasic response in the secretion of gonadotrophin releasing hormone in ovariectomized ewes injected with oestradiol. J. Endocrinol. 123:375-382. https:// doi.org/10.1677/joe.0.1230375.

Casao, A., J. Abecia, J. Cebrián-Pérez, T. Muiño-Blanco, M. Vázquez, and F. Forcada. 2010. The effects of melatonin on in vitro oocyte competence and embryo development in sheep. Span. J. Agric. Res. 8:35-41. https://doi.org/10.5424/sjar/2010081-1141.

Celi, I., M. Gatica, J. Guzmán, L. Gallego-Calvo, and L. Zarazaga. 2013. Influence of the male effect on the reproductive performance of female Payoya goats implanted with melatonin at the winter solstice. Anim. Reprod. Sci. 137:183-188. https://doi.org/10.1016/j. anireprosci.2013.01.015.

Clark, J., W. Schrader, and B. O'Malley. 1992. Mechanisms of steroid hormones action. Pages 35-90 in Textbook of Endocrinology. J. D. Wilson and D. W. Foster, ed. Saunders, Philadelphia, PA.

Contreras-Villarreal, V., C. Meza-Herrera, R. Rivas-Muñoz, O. AngelGarcia, J. Luna-Orozco, E. Carrillo, M. Mellado, and F. VélizDeras. 2016. Reproductive performance of seasonally anovular mixed-bred dairy goats induced to ovulate with a combination of progesterone and eCG or estradiol. Anim. Sci. J. 87:750-755. https://doi.org/10.1111/asj.12493.

Cunha, G. R., P. Cooke, and T. Kurita. 2004. Role of stromal-epithelial interactions in hormonal responses. Arch. Histol. Cytol. 67:417-434. https://doi.org/10.1679/aohc.67.417.

DeNicolo, G., S. Morris, P. Kenyon, P. Morel, and T. Parkinson. 2008. Melatonin-improved reproductive performance in sheep bred out of season. Anim. Reprod. Sci. 109:124-133. https://doi. org/10.1016/j.anireprosci.2007.10.012.

Durotoye, L. A., G. Webley, and R. Rodway. 1997. Stimulation of the production of progesterone by the corpus luteum of the ewe by the perfusion of melatonin in vivo and by treatment of granulosa cells with melatonin in vitro. Res. Vet. Sci. 62:87-91. https://doi. org/10.1016/s0034-5288(97)90126-0.

Fabre-Nys, C., and G. Martin. 1991. Roles of progesterone and oestradiol in determining the temporal sequence and quantitative expression of sexual receptivity and the preovulatory LH surge in ewe. J. Endocrinol. 130:367-379. https://doi.org/10.1677/joe.0.1300367.

FASS (Federation of Animal Science Societies). 2010. Guide for the Care and Use of Agricultural Animals in Research and Teaching. 3rd ed. Federation of Animal Science Societies, Champaign, IL.

Fatet, A., M. Pellicer-Rubio, and B. Leboeuf. 2011. Reproductive cycle of goats. Anim. Reprod. Sci. 124:211-219. https://doi. org/10.1016/j.anireprosci.2010.08.029.

Fonseca, J. F., J. Bruschi, I. Santos, J. Viana, and A. Magalhães. 2005. Induction of estrus in non-lactating dairy goats with differ- 
ent estrous synchrony protocols. Anim. Reprod. Sci. 85:117-124. https://doi.org/10.1016/j.anireprosci.2004.03.005.

Fonseca, J. F., C. Torres, A. Santos, V. Maffili, L. Amorim, and E. Moraes. 2008. Progesterone and behavioral features when estrous is induced in Alpine goats. Anim. Reprod. Sci. 103:366-373. https://doi.org/10.1016/j.anireprosci.2007.05.013.

Forcada, F., J. Abecia, J. Cebrián-Perez, T. Muiño-Blanco, J. Valares, I. Palacin, and A. Casao. 2006. The effect of melatonin implants during the seasonal anestrus on embryo production after superovulation in aged high prolificacy Rasa Aragonesa ewes. Theriogenology 65:356-365. https://doi.org/10.1016/j. theriogenology.2005.05.038.

Forcada, F., J. Abecia, O. Zuñiga, and J. Lozano. 2002. Variation in the ability of melatonin implants inserted at two different times after the winter solstice to restore reproductive activity in reduced seasonality ewes. Aust. J. Agric. Res. 53:167-173. https://doi. org/10.1071/ar00172.

Forcada, F., L. Zarazaga, and J. Abecia. 1995. Effect of exogenous melatonin and plane of nutrition after weaning on estrous activity, endocrine status and ovulation rate in Salz ewes lambing in the seasonal anestrus. Theriogenology 43:1179-1193. https://doi. org/10.1016/0093-691x(95)00090-u.

Fukui, Y., R. Itagaki, N. Ishida, and M. Okada. 2001. Effect of different hCG treatments on fertility of estrus-induced and artificially inseminated ewes during the non-breeding season. J. Reprod. Dev. 47:189-195. https://doi.org/10.1262/jrd.47.189.

Gimeno, M., A. Fuentes, A. Landa, N. Sterinspeziale, D. Cardinali, and A. Gimeno. 1980b. Melatonin inhibitor of prostaglandin release. Acta Physiol. Latino Americana 30:38-39. https://doi. org/10.1016/0014-2999(80)90098-9.

Gimeno, M. F., A. Landa, N. Sterin-Speziale, D. Cardinali, and A. Gimeno. 1980a. Melatonin blocks in vitro generation of prostaglandin by the uterus and hypothalamus. Eur. J. Pharmacol. 62:309-317. https://doi.org/10.1016/0014-2999(80)90098-9.

Gonzalez-Bulnes, A., P. Pallares, and M. Vazquez. 2010. Ultrasonographic imaging in small ruminant reproduction. Reprod. Domest. Anim. 45:9-20. http://dx.doi.org/https://doi.org/10.1111/j.14390531.2010.01640.x.

Grattan, D. R. 2002. Behavioral significance of prolactin signaling in the central nervous system during pregnancy and lactation. Reproduction 123:497-506. https://doi.org/10.1530/rep.0.1230497.

Hafez, B., and E. S. E. Hafez. 2000. Reproduction in Farm Animals. 7th ed. Lippincott, Williams and Wilkins, Philadelphia, PA. https://doi.org/10.1002/9781119265306.

Hashem, N. M., K. El-Azrak, A. Nour El-Din, T. Taha, and M. Salem. 2015. Effect of GnRH treatment on ovarian activity and reproductive performance of low-prolific Rahmani ewes. Theriogenology 83:192-198. https://doi.org/10.1016/j.theriogenology.2014.09.016.

Helmer, S. D., P. J. Hansen, W. W. Thatcher, J. W. Johnson, and F W. Bazer. 1989. Intrauterine infusion of highly enriched bovine trophoblast protein-1 complex exerts an antiluteolytic effect to extend corpus luteum lifespan in cyclic cattle. J. Reprod. Fertil. 87:89-101. https://doi.org/10.1530/jrf.0.0870089.

Honparkhe, M., P. Ghuman, J. Singh, and G. Dhaliwal. 2011. A CIDR-based AI protocol establishes pregnancy in repeat breeder dairy cattle. Indian J. Anim. Sci. 81:340-343.

Ishwar, A., and M. Memon. 1996. Embryo transfer in sheep and goats: A review. Small Rumin. Res. 19:35-43. https://doi. org/10.1016/0921-4488(95)00735-0.

Jerome, A., and N. Srivastava. 2012. Prostaglandins vis-à-vis bovine embryonic mortality: A review. Asian Pacific J. Reprod. 1:238 246. https://doi.org/10.1016/S2305-0500(13)60085-8.

Kann, G., and J. Martinet. 1975. Prolactin levels and duration of postpartum anoestrus in lactating ewes. Nature 257:63-64. https://doi. org/10.1038/257063a0.

Kaya, S., C. Kaçar, D. Kaya, and S. Aslan. 2013. The effectiveness of supplemental administration of progesterone with $\mathrm{GnRH}, \mathrm{hCG}$ and PGF2 $\alpha$ on the fertility of Tuj sheep during the non-breeding season. Small Rumin. Res. 113:365-370. https://doi.org/10.1016/j. smallrumres.2013.03.018.
Kermani Moakhar, H., H. Kohram, A. Zareh Shahneha, and T. Saberifar. 2012. Ovarian response and pregnancy rate following different doses of eCG treatment in Chall ewes. Small Rumin. Res. 102:63-67. https://doi.org/10.1016/j.smallrumres.2011.09.017.

Khan, T. H., P. M. Hastie, N. F. Beck, and M. Khalid. 2003. hCG treatment on day of mating improves embryo viability and fertility in ewe lambs. Anim. Reprod. Sci. 76:81-89. http://dx.doi.org/ https://doi.org/10.1016/s0378-4320(02)00194-x.

Kumar, S., and G. Purohit. 2009. Effect of a single subcutaneous injection of melatonin on estrous response and conception rate in goats. Small Rumin. Res. 82:152-155. https://doi.org/10.1016/j. smallrumres.2009.02.005.

Lawson, R. A., and L. Cahill. 1983. Modification of the embryo maternal relationship in ewes by progesterone treatment early in the estrous cycle. J. Reprod. Fertil. 67:473-475. https://doi. org/10.1530/jrf.0.0670473.

Leyva, V., B. Buckrell, and J. Walton. 1998. Follicular activity and ovulation regulated by exogenous progestagen and PMSG in anestrous ewes. Theriogenology 50:377-393. https://doi.org/10.1016/ s0093-691x(98)00147-2.

Mann, G. E. 2002. Corpus luteum function and early embryonic death in the bovine. Pages 300-306 in Proceedings of the XXII World Buiatrics Congress, Hannover, Germany. Publisher, City, Country.

Mellado, J., F. Veliz, A. De Santiago, C. Meza-Herrera, and M. Mellado. 2014. Buck induced estrus in grazing crossbred goats during increasing photoperiods in northern Mexico. Vet. Zootech. 66:40-46.

Menchaca, A., V. Miller, V. Salveraglio, and E. Rubianes. 2007. Endocrine, luteal and follicular responses after the use of the short-term protocol to synchronize ovulation in goats. Anim. Reprod. Sci. 102:76-87. https://doi.org/10.1016/j.anireprosci.2006.10.001.

Misztal, T., K. Romanowicz, and B. Barcikowski. 1997. Natural and melatonin stimulated changes in the circadian rhythm of prolactin secretion in the ewe during seasonal anestrus. Neuroendocrinology 66:360-367. https://doi.org/10.1159/000127259.

Mondal, M., C. Rajkhowa, and B. Prakash. 2006. Relationship of plasma estradiol-17 $\beta$, total estrogen, and progesterone to estrus behavior in mithun (Bos frontalis) cows. Horm. Behav. 49:626-633. https://doi.org/10.1016/j.yhbeh.2005.12.015.

Mori, Y., K. Maeda, T. Sawasaki, and Y. Kano. 1985. Photoperiodic control of prolactin secretion in the goat. Jpn. J. Anim. Reprod. 31:9-15. https://doi.org/10.1262/jrd1977.31.9.

Nephew, K. P., H. Cardenas, K. McClure, T. Ott, F. Bazer, and W. Pope. 1994. Effects of administration of human chorionic gonadotropin or progesterone before maternal recognition of pregnancy on blastocyst development and pregnancy in sheep. J. Anim. Sci 72:453-458. https://doi.org/10.2527/1994.722453x.

Noël, B., J. Bister, B. Pierquin, and R. Paquay. 1994. Effects of FGA and PMSG on follicular growth and LH secretion in Suffolk ewes. Theriogenology 41:719-727. https://doi.org/10.1016/0093691x(94)90181-h.

Noël, B., S. Mandiki, B. Perrad, J. Bister, and R. Paquay. 1999. Terminal follicular growth, ovulation rate and hormonal secretion after melatonin pretreatment prior to FGA-PMSG synchronisation in Suffolk ewes at the onset of the breeding season. Small Rumin. Res. 32:269-277. https://doi.org/10.1016/s0921-4488(98)00187-4.

NRC (National Research Council). 2007. Nutrient Requirements of Small Ruminants. National Academies Press, Washington, DC. https://doi.org/10.17226/11654

Ollier, S., X. Zhao, and P. Lacasse. 2013. Effect of prolactin-release inhibition on milk production and mammary gland involution at drying-off in cows. J. Dairy Sci. 96:335-343. https://doi. org/10.3168/jds.2012-5955.

Parks, J. 2004. Hormones of the Hypothalamus and Pituitary. Elsevier, Philadelphia, PA.

Plante, C., P. Hansen, S. Martinod, B. Siegenthaler, W. Thatcher, J Pollard, and M. Leslie. 1989. Effect of intrauterine and intramuscular administration of recombinant bovine interferon-alpha 1 on luteal lifespan in cattle. J. Dairy Sci. 72:1859-1865. https://doi. org/10.3168/jds.S0022-0302(89)79304-8.

Prandi, A., G. Romagnoli, F. Chiesa, and C. Tamanini. 1987. Plasma prolactin variations and onset of ovarian activity in lactating 
anestrous goats given melatonin. Anim. Reprod. Sci. 13:291-297. https://doi.org/10.1016/0378-4320(87)90066-2.

Ramukhithi, F., T. Nedambale, B. Sutherland, J. Petrus, C. Greyling, and K. Lehloenya. 2012. Oestrous synchronization and pregnancy rate following artificial insemination (AI) in South African indigenous goats. J. Appl. Anim. Res. 40:292-296. https://doi.org/10.1 080/09712119.2012.685280.

Rowe, J. D., L. A. Tell, J. L. Carlson, R. W. Griffith, K. Lee, H. Kieu, S. Wetzlich, and D. Hallford. 2010. Progesterone milk residues in goats treated with CIDR-G inserts. J. Vet. Pharmacol. Ther. 33:605-609. https://doi.org/10.1111/j.1365-2885.2010.01172.x.

Schmitt, E. J., C. Barros, P. Fields, M. Fields, T. Diaz, J. Kluge, and W. Thatcher. 1996. A cellular and endocrine characterization of the original and induced corpus luteum after administration of a gonadotropin-releasing hormone agonist or human chorionic gonadotropin on day five of the estrous cycle. J. Anim. Sci. 74:19151929. https://doi.org/10.2527/1996.7481915x.

Sheth, A., K. Wadadekar, S. Moodbidri, K. Janakiraman, and M. Paramesh. 1978. Seasonal alteration in the serum prolactin and LH levels in the water buffaloes. Curr. Sci. 47:75-77.

Souza, J. M. G., C. A. A. Torres, A. L. R. S. Maia, F. Z. Brandao, J. H. Bruschi, J. H. M. Viana, E. Oba, and J. F. Fonseca 2011. Autoclaved, previously used intravaginal progesterone devices induces estrus and ovulation in anestrous Toggenburg goats. Anim. Reprod. Sci. 129:50-55. https://doi.org/10.1016/j. anireprosci.2011.09.012.

Spencer, T. E., and F. W. Bazer. 1996. Ovine interferon tau suppresses transcription of the estrogen receptor and oxytocin receptor genes in the ovine endometrium. Endocrinology 137:1144-1147. https:// doi.org/10.1210/endo.137.3.8603586.

Spencer, T., G. Johnson, F. Bazer, and R. Burghardt. 2004. Implantation mechanisms: Insights from the sheep. Reproduction 128:657668. https://doi.org/10.1530/rep.1.00398.

Steel, R., and T. Torrie. 1980. Principles and Procedures of Statistics. 2nd ed. McGraw Hill, New York.

Sullivan, R. R., B. Faris, D. Eborn, D. Grieger, A. Cino-Ozuna, and T. Rozell. 2013. Follicular expression of follicle stimulating hormone receptor variants in the ewe. Reprod. Biol. Endocrinol. 11:113120. https://doi.org/10.1186/1477-7827-11-113.

Vázquez, M. I., F. Forcada, A. Casao, J. Abecia, C. Sosa, and I. Palacín. 2010. Undernutrition and exogenous melatonin can af- fect the in vitro developmental competence of ovine oocytes on a seasonal basis. Reprod. Domest. Anim. 45:677-684. https://doi. org/10.1111/j.1439-0531.2008.01329.x.

Vázquez, M. I., F. Forcada, C. Sosa, A. Casao, I. Sartore, A. Fernández-Foren, A. Meikle, and J. Abecia. 2013. Effect of exogenous melatonin on embryo viability and uterine environment in undernourished ewes. Anim. Reprod. Sci. 141:52-61. https://doi. org/10.1016/j.anireprosci.2013.07.007.

Yue, C., L. Du, W. Zhan, X. Zhu, X. Kong, and Z. Jia. 2010. Expression of prolactin receptor mRNA after melatonin manipulated in Cashmere goats skin during Cashmere growth. Asian-Aust. J. Anim. Sci. 23:1291-1298. https://doi.org/10.5713/ajas.2010.10010.

Zarazaga, L. A., I. Celi, J. Guzmán, and B. Malpaux. 2011a. The effect of nutrition on the neural mechanisms potentially involved in melatonin-stimulated LH secretion in female Mediterranean goats. J. Endocrinol. 211:263-272. https://doi.org/10.1530/JOE-11-0225.

Zarazaga, L. A., I. Celi, J. Guzmán, and B. Malpaux. 2012a. Enhancement of the male effect on reproductive performance in female Mediterranean goats with long day and/or melatonin treatment. Vet. J. 192:441-444. https://doi.org/10.1016/j.tvjl.2011.09.012.

Zarazaga, L. A., M. Gatica, I. Celi, and J. Guzmán. 2012b. Reproductive performance is improved during seasonal anoestrus in Murciano-Granadina and Payoya goats when the females, but not always the males, receive melatonin implants. Reprod. Domest. Anim. 47:436-442. https://doi.org/10.1111/j.1439-0531.2011.01899.x.

Zarazaga, L. A., M. Gatica, I. Celi, J. Guzmán, and B. Malpaux 2009. Effect of melatonin implants on sexual activity in Mediterranean goat females without separation from males. Theriogenology 72:910-918. https://doi.org/10.1016/j.theriogenology.2009.05.020.

Zarazaga, L. A., M. Gatica, I. Celi, J. Guzmán, and B. Malpaux. 2011b. Artificial long days in addition to exogenous melatonin and daily contact with bucks stimulate the ovarian and oestrous activity in Mediterranean goat females. Animal 5:1414-1419. https:// doi.org/10.1017/S1751731111000413.

Zúñiga, O., F. Forcada, and J. Abecia. 2002. The effect of melatonin implants on the response to the male effect and on the subsequent cyclicity of Rasa Aragonesa ewes implanted in April. Anim. Reprod. Sci. 72:165-174. https://doi.org/10.1016/s03784320(02)00117-3. 